\title{
Demobilizing and Reintegrating FARC Fighters: The CHALlENGES FACED TO END THE FOREVER WAR
}

\section{Christian Vianna de Azevedo}

Federal Police Departament - Brazil

$$
\text { × }
$$

\begin{abstract}
Fuerzas Armadas Revolucionarias de Colombia - FARC has consolidated its position as the longest surviving and the most entrenched guerrilla movement in all of the Americas. FARC has been steadily weakened after significant leadership losses, more than half of its foot soldiers and a substantial amount of its experienced mid level commanders. Yet peace is not in sight. Colombian civil war happens to be the stereotypical intractable conflict. Colombian state forces have been increasingly powerful, yet the guerrilla, although crippled, is entrenched and resilient. The government has relied on the demobilization program as a way out for a conflict that seems ripe for resolution. Colombian demobilization program is called PAHD - Programa de Atención Humanitaria al Desmovilizado. It has been highly regarded and approved by the population and by the demobilized as well. One of the greatest concerns of the government is about the life of the ex-fighters after demobilization. The economic reintegration has proven to be arduous and recidivism may be a problem. Yet there are other concerns about the defeat of FARC that have to be worked together with the demobilization program so peace can be finally achievable.
\end{abstract}

KEYwORDS: FARC. Guerrilla. Colombia. Military Forces. Security. Insurgency. Recruitment. Demobilization. Reintegration. Criminal Organization. Governance.

\section{INTRODUCTION}

Fuerzas Armadas Revolucionarias de Colombia - FARC has consolidated its position as the longest surviving and the most entrenched guerrilla movement in all of the Americas. It reached its peak by the turn of the 21 st century, when its standing army was comprised by approximately 18,000 combatants and it controlled more than a third of Colombian territory. Nevertheless, from the year 2000 onwards, FARC has been steadily weakened after significant leadership losses, more than half of its foot soldiers and a substantial amount of its experienced mid level commanders. (MARKS, 2007; 
PÉCAUT, 2008; SAAB; TAYLOR, 2009; RUEDA, 2009; ECCARIUSKELLY, 2012). All this happened mainly due to successful military operations led by the Colombian Army together with a government demobilization program. (PECENY; DURNAN, 2006; WENTZ, 2009; SAAB; TAYLOR, 2009; PHILLIPS, 2012; JONSSON; JOHNSON, 2013).

In spite of the ongoing peace talks with FARC in Havana/Cuba, peace is not in sight. Colombian civil war happens to be the stereotypical intractable conflict. What began five decades ago as a Marxist revolutionary fight against a political system has escalated to a bloody war over resources, where military, paramilitary, guerrillas, domestic elites and multinational actors contend for the control of the country. (THEIDON, 2009; SARRIAS, 2011; CUNNINGHAM et ali, 2012; INCE, 2013). As reported by the Colombian government in recent statistics, the conflict with FARC has left almost 220,000 dead and more than 5,7 million internally displaced ${ }^{1}$. (INCE, 2013). Additionally, to make matters even worse, Colombia's government forces face other merging challenges: a vast drug trade, illegal markets, large inaccessible territory, geographically challenging terrain, thinly populated jungle, colossal inequality and weak or even no state presence in peripheral regions, which makes an outright military victory highly unlikely. (JUDICE, 2007; CRISISGROUP, 2012; JONSSON; JOHNSON, 2013).

The alternative strategy to drain FARC's human resources besides direct military action is Colombia's demobilization program, which was created in 2002 in President Álvaro Uribe's administration within the broader 'democratic security' policy. (ARIAS, et ali, 2010; ROSENAU et ali, 2013). This defector/demobilization, disarmament and reintegration program invites fighters to demobilize and collaborate with the government giving information about FARC in exchange for education, job training, psychological help and to some extent, legal impunity. The huge numbers of combatants who already took advantage of this program since 2002 is impressive. That action helped Colombian forces to cripple FARC even further. (ARIAS, et ali, 2010; ROSENAU et ali, 2013; JONSSON; JOHNSON, 2013).

1 Along the last decades the guerillas, the paramilitaries and the Colombian military have perpetrated atrocities and all kinds of human rights violations. As a consequence of the widespread violence and the escalating barbarities also a massive internal and cross border displacement happened. In addition, thousands of people have been kidnapped, disappeared, tortured, forcefully recruited by the armed groups. All this resulted in a major humanitarian crisis. (PEÑARANDA et ali. 2003; UNHCR, 2014). For the purpose of this article we will not descend into details on this subject. . 
By 2006, FARC saw its forces decline to nearly half of what it was in $2001^{2}$. The remainder of its troops was constantly on the move as they were unable to establish fixed bases or even long-term rest areas. Nevertheless, they managed to adapt tactics and linger on.

Despite its tactical changes, FARC is nowadays only a scattered shadow of what it was on the turn of the 21 st century. Its decline is under way and seems irreversible. FARC has lost strategic initiative, thus cornered into adopting a defense attitude at all levels and further, it has had its logistics systematically sapped. The consequence is FARC's current inability to control or hold territory. (CRANDALL, 2011; OSPINA; MARKS, 2014).

Even though, the possibilities of peace do not seem very close. Both sides realized that winning this war militarily is hardly feasible. Colombian state forces have been increasingly powerful, yet the guerrilla, although crippled, is entrenched and resilient. (ENC, 2009; JONSSON; JOHNSON, 2013). The government has been placing its bets in the demobilization program for it may be a way out for a conflict that seems ripe for resolution.

\section{Current Demobilization and Reintegration Program in Colombia. An Outline}
Desmovilicese, recupere su lugar: su familia, su pais, la libertad, la vida y las nuevas oportunidades lo esperan ${ }^{3}$. (PAHD advertising, in: SARRIAS, 2011, p. 110).

Colombian demobilization program is called PAHD - Programa de Atención Humanitaria al Desmovilizado. It derives from the more general DDR that stands for 'Disarmament, Demobilization and Reintegration'4, as defined below:

2 Still from 2006 to 2008 FARC lost 17,274 members, including 5,316 through demobilizations and the remainder through captures and casualties. Moreover it has further lost 20 operational fronts. (SAAB; TAYLOR, 2009).

3 Demobilize! Recover your place, your family, your country, and freedom. Life and other opportunities are waiting for you. (Our translation).

4 The process begins with 'disarming', which takes place during a ceremony sponsored by the government. That is followed by another ceremony, the 'demobilization' whose purpose is to reinforce a psychological change from 'enemy to friend' in the minds of the individuals. After these ceremonies are held, the process follows in a discrete way and entails confessions, disclosure of information through a series of interviews, and physical and psychological exams. The last step is the long reintegration process. (JUSTICE, 2007). 
The objective of the DDR is to contribute to security and stability in post-conflict environments so that recovery and development can begin. The DDR of ex-combatants is a complexprocess, with political, military, security, humanitarian and social-economic dimensions. It aims to deal with a post-conflict security problem that arises when ex-combatants are left without livelihood or support networks, other than their former comrades, during the vital transition period from conflict to peace and development. Through a process of removing weapons from the hands of the combatants, taking the combatants out of the military structures and helping them to integrate socially and economically into society. (UNDDR, 2014).

The DDR processes implemented in different countries of the world reflect their domestic dynamics and context. Hence, the countries need to frame their DDR policies to their social demands that come both from the ex-fighters and the general public, and additionally with the budget and political limitations of their governments. (ARIAS et ali, 2010). In the case of Colombia, DDR was aimed to promote the individual demobilization and, while preparing the individual for reintegration, coax him to collaborate with the government supplying information about the guerrilla. Therefore Colombian government established some specific objectives to its DDR, which are: to encourage the fighters to demobilize, to prevent FARC's forced recruitment, to make the community sensible to the issue, to gather intelligence, to reduce the number of FARC fighters, to erode the morale of FARC and to give the demobilized individuals what is necessary to carry on with their lives and be fully reintegrated within society. (COLOMBIA, 2008).

Anaya (2007) suggests four concepts revolving the process of demobilization and reintegration in Colombia: demobilization, reincorporation, reintegration, and reconciliation. Demobilization is understood as the formal disbanding of military ranks at the individual level. The demobilized combatant is a person that voluntarily abandons the guerrilla and joins the state sponsored DDR program, after his verification of past affiliation with the guerrilla is done. Reincorporation is the procedure that transforms a criminal into a law-abiding civilian. It is a process whose goal is reintegrating the person into civilian life. Surely the individual must intend to be part of the process and must have decided to abandon his illegal organization. Reintegration refers to long-term programs that 
include a cash compensation, psychological assistance and training aimed to ease his economic and social reintegration. Reconciliation is designed to get the parties involved (the general public and the demobilized fighter) to recognize and accept each other diplomatically. (ANAYA, 2007).

The current PAHD program was created under president Uribe's administration in 2002. It is part of the strategic tool within the extensive 'Democratic Security Policy'. The program is run by a branch of the Ministry of Defense in cooperation with several other ministries, notably: public health, justice, social protection and interior affairs. (PHILLIPS, 2012; ROSENAU et ali, 2013).

The PAHD is ruled by the law 975/2005, known as Ley de Justicia y $\mathrm{Paz}^{5}$. Under Uribe's PAHD program, the first demobilized combatants were members of paramilitary groups operating under AUC - Auto Defensas Unidas de Colombia. (JUSTICE, 2007; PHILLIPS, 2012). These fighters agreed to demobilize in 2003 and turn in their arms. Between 2003 and 2006 an estimate of 32,000 paramilitary combatants demobilized collectively. (JUSTICE, 2007; ROSENAU et ali, 2013) Following this wave of demobilization, the next groups of fighters to demobilize were FARC and ELN - Ejército de Liberación Nacional ${ }^{6}$ members. These have been demobilizing individually, and nowadays they number approximately 21,000. (ROSENAU et ali, 2013). The DDR agreements of 2003 were encompassed by the law 975/2005, and thus gave these demobilization processes a legal framework. Not to mention that the law 975/2005 has been amended several times in order to be more adjustable to recent DDR developments ${ }^{7}$.

5 Peace and justice law. (Our translation). Its roots trace back to 1982, when Colombia's former president Belisario Betancur, backed by the law 35/1982, convinced some of the guerrilla groups to sign truces and demobilize. These agreements fell apart, but they laid foundations to the first successful demobilization of illegal armed groups in the 1990s. These accords developed over time leading to the issue of the law $418 / 1997$ and later the law $782 / 2002$. These were the predecessors of law $975 / 2005$. The law $418 / 1997$ was designed to individual desertions, while law $782 / 2002$ was aimed at collective DDR. Law 975/2005 is targeted at both. (MINDEFENSA, 2005; JUSTICE, 2007; SARMIENTO, 2013).

$6 \mathrm{ELN}$ is a leftwing guerrilla group active in Colombia.

7 The first amendments were done to prevent AUC to back out of the agreement, and later the law incorporated observations from the critics, it had to adapt to the updated jurisprudence being ruled by Colombian courts of law in respect to some of its operational details. (JUSTICE, 2007). 
FARC demobilized personnel statistics

\begin{tabular}{|c|c|c|c|c|c|c|c|c|c|c|c|c|}
\hline Year & $\mathbf{0 2}$ & $\mathbf{0 3}$ & $\mathbf{0 4}$ & $\mathbf{0 5}$ & $\mathbf{0 6}$ & $\mathbf{0 7}$ & $\mathbf{0 8}$ & $\mathbf{0 9}$ & $\mathbf{1 0}$ & $\mathbf{1 1}$ & $\mathbf{1 2}$ & $\mathbf{1 3}$ \\
\hline Demob & 529 & 1376 & 1300 & 1135 & 1158 & 2480 & 3027 & 2128 & 2009 & 1308 & 979 & 1110 \\
\hline
\end{tabular}

Table above: FARC individual demobilized statistics per year. (MINDEFENSA, 2014).

However well intentioned, the law has been criticized from the start. The critics say it does not measure up to international standards because of its excessively lenient terms, as a result, a bad deal for Colombians as it sets some precedents that can be disastrous in future negotiations. (JUDICE, 2007; MENDEZ, 2012). It is said that this law grants impunity to fighters accused of human rights abuses for it renders them reduced sentences for the crimes committed. Moreover, it provides little assistance or reparation to the victims. ${ }^{8}$ (JUDICE, 2007; MENDEZ, 2012). Indeed, the complaints about the leniency of this law are true. Although this law requires the demobilized to come clean with their crimes, the Colombian state neither provided enough resources for them to do so, nor assigned enough number of prosecutors to investigate the many complex cases whose evidence is often hidden. There are other cases in which high profile guerrillas are given amnesty in exchange for collaboration. Additionally, the law does not require the authorities to look for human rights violations. (PORCH; RASMUSSEN, 2008; MENDEZ, 2012).

The basic reason why the government of Colombia resorted upon DDR was the fact that the alternative was to probably kill or capture every guerrilla fighter; and, simply put, that would be impossible. There is no record of any insurgency in recent history that was entirely defeated through military combat only. (JUSTICE, 2007; CONNABLE; LIBICKI, 2010). DDR comes in a way that could be effective as a tool to manage the conflict. If the program is well conducted, it provides an acceptable way out for the fighters, which in turn helps the struggle to end long before it would otherwise happen. (JUSTICE, 2007; CONNABLE; LIBICKI, 2010; JONSSON; JOHNSON, 2013).

8 For more on this issue see CJA - Center For Justice and Accountability. (CJA, 2014), New York Times article: "Colombia Capitulation" (NYTIMES, 2005), and Inter American Commission for Human Rights. Follow-up on the demobilization process of AUC in Colombia. (CIDH, 2007). 


\title{
3. A Life in the Column. Why do They Join? Why do THEY LEAVE?
}

\begin{abstract}
Estoy cansada de las FARC, cansada de la gente, cansada de la vida comunal, cansada de nunca tener nada para mi sola (...) He tenido muchas dudas sobre las FARC, la revolución, sobre las cosas que hacemos (...) Me muevo aqui como un pez en el agua, estas montañas son mi hogar, la guerrilla es mi vida, mi familia9. (TANJA NIJMEIJER ${ }^{10}$, in ARIAS et ali, 2010, p. 09).
\end{abstract}

Prior to further speaking about Colombia's PAHD and its peculiar issues and challenges we need to turn to the questions: Why do people join FARC in the first place $^{11}$ ? Why do they leave?

Academics and the Colombian military alike share a common explanation for the basic lure of FARC. The guerrilla group mainly operates in rural parts of the country; some of these places are quite remote. Apart from deep jungle camps, FARC generally establish its bases near rural communities and they embed within local society. Therefore the local inhabitants grow up having daily contact with the fighters or people involved with them. Consequently, joining the guerrilla is something quasi-natural. Or even part of the tradition in some regions. (ANAYA, 2007; SAAB; TAYLOR, 2008; THEYDON, 2009). Apart from that fact there are a set of other reasons that are common sense among academics, which are: forced recruitment, allure of weapons and uniforms, false promises of good salaries and good food, political conviction, influence of friends, false expectations of an easier life, tediousness of former life and family ties with armed groups ${ }^{12}$.

9 I am tired of FARC, tired of the people, tired of the communal life, tired of not having anything for me only (...) I have a lot of doubts about FARC, the revolution and the things we do (...) Here I move like a fish in the water, these mountains are my home, the guerrilla is my life, my family. (Our translation.).

10 Tanja Nijmeijer is a Dutch FARC fighter. She has been with the guerrilla since 2002. She is now part of the FARC negotiating team in the current peace talks with the government. Her personal journal 'Crónica de una desilusión' was found in 2007 during a military raid in her camp. (NACIÓN, 2010; REFSHAUGE, 2012).

11 For the purpose of this piece we will focus on the primary and main reasons for joining/leaving FARC. There are some other layers to this issue that go back deep into the socio-cultural scenario of Colombia that would need an 'in depth' argumentation which is out of the scope of this article.

12 To sort out all those reasons into accurate distribution percentage is a hard task. The academics cited above disagree regarding the precise figures. Nevertheless, for further reading, there is this specific study conducted by ROSENAU et ali (2013) in which they were granted access to the PAHD demobilized militants database. The figures showed in their studies are enlightening. 
(ANAYA, 2007; SAAB; TAYLOR, 2008; THEIDON, 2009; NADER, 2013; ROSENAU et ali, 2013).

The majority of FARC's recruits fall into three categories: minors $^{13}$ (under 18 years of age), peasants/rural people with almost no formal education and university students. (THEIDON, 2009; NUSSIO; HOWE, 2012; ROSENAU et ali, 2013). About $50 \%$ to $65 \%$ of all FARC fighters joined when they were minors. (THEIDON, 2009; NUSSIO; HOWE, 2012).

For insurgent organizations, underage recruits have considerable appeal. In the country's impoverished hinterlands, the supply of children eager to escape neglect, family abuse and lack of opportunity is substantial. As Colombian forces have chipped away groups like $F A R C$, the underage population functions as an important manpower reservoir. Perceived as malleable by militant commanders, children, particularly from rural areas are seen as physically hardy and therefore suitable for the rigors of a life in a guerrilla column. (ROSENAU et ali, 2013, p 5).

The radicalization of university students is a good topic for study ${ }^{14}$. FARC roams around universities because it is interested in recruiting relatively well-educated manpower into its ranks, for it is in short supply of educated mid-level commanders and also it looks towards the future when the urban campaign is deemed to start. Yet fighters with a college background form a very small percentage of FARC's ranks. Along its five decades of existence FARC has been a mostly rural insurgent group that has drawn the majority of its personnel from a peasant base. (SAAB; TAYLOR, 2008; THEYDON, 2009; ROSENAU et ali, 2013).

Once recruited the individual quickly realizes how harsh the conditions in a guerrilla column can be. One of the most difficult things he has to cope with is the loss of individuality. (NADER, 2013). Together with the element of isolation, the loss of individuality is a FARC's requirement for survival. Basically, the militant is given an entirely new name and soon he loses contact with his family and friends. FARC's aim is to erase his past life. Therefore family ties of FARC members are shattered as a consequence

13 Under the United Nations criteria, any person under the age of 18 who is part of an armed group, whether or not bears arms, falls under the concept of "child soldier". (UN, 2007).

14 The university environment as it is highly politicized it is an open door for recruiters to move around freely, deliver political messages and get in touch with potential fighters. (ROSENAU et ali, 2013). 
of the group's need to keep its cohesion and avoid desertions that come from family pressure. Besides, everything is communal; the fighter does not own anything and does not get paid. These rigid requirements aim to keep the agents of the government from infiltrating the ranks and also to shield the group and its militants from outside world. Altogether, what it wants to say is that FARC's way is the only way. (ARIAS et ali, 2010; NADER, 2013).

The defection rate among FARC members was at its peak around 2008 and 2009. (MINDEFENSA, 2014). It was not a coincidence that those years were the lowest point in FARC's strength since the year 2000. (JONSSON; JOHNSON, 2013). According to PADH database one of the important reasons the combatants deserted the guerrilla was the evergrowing pressure of the government forces that blocked their movement, sapped their logistics and inflicted them heavy casualties. Since 2002 FARC has been steadily weakened. The intensity of that assailment was mostly felt in 2008 and 2009, after years of constant defeat. (BAÉZ, 2009).

Along Uribe's government there was a strategy, which was given priority. This was an organized effort by the Ministry of Defense to focus the armed forces and national police in engaging in a campaign to increase the demobilization of FARC fighters. (WENTZ, 2009; BAÉZ, 2009; PHILLIPS, 2012). The government forces were encouraged to draw the fighters out of the guerrilla. Colombian government came up with a plan that praised military units for demobilizing statistics. The number of defections reflected positively in the efficiency ranking of the military unit, which was further ranked for its efficiency based on how many militants it was able to coax out of FARC. (BAÉZ, 2009; ENC, 2009). That fact enabled the government to drag more fighters out of FARC.

Along with these first layers of reasons for defections, there are three other subjacent ones that are directly linked to those mentioned above. The first has to do with the ideological disenchantment with the guerrilla. The militants saw the deviation of the revolutionary principles into organized crime. The second deals with the harsh life endured in FARC: hunger, fatigue, and loss of individuality, isolation and physical abuse by commanders. The third was the wish to reconnect with their families and rebuild their lives. (ANAYA, 2007; BAÉZ, 2009; ROSENAU et ali, 2013). 


\title{
4. Colombia's PAHD. Is it the Clue to End the War?
}

\author{
Soledad, hambre... desde el dia que usted formó parte de la guer- \\ rilla, una Colombia entera lo espera con las manos abiertas para \\ que sea productivo ${ }^{15}$. (PAHD advertising, in: SARRIAS, 2011, \\ p 110)
}

The DDR conducted in Colombia has been highly regarded and approved by the population and by the demobilized as well. The Colombian Reintegration Agency ${ }^{16}$ known as ACR is the most trusted and regarded of all Colombian Institutions. (NUSSIO; HOWE, 2012). Thus, DDR has an underlying potential to build trust among population and former insurgents. But that potential will cement if inserted in a wide peace-building framework and if managed with realistic expectations.

Besides, there is an ongoing peace talk with the FARC since $2012^{17}$. If this negotiation evolves satisfactorily the demobilizing process will be much faster. But regardless the outcomes of these talks the DDR has been running steadily. (INCE, 2013; MINDEFENSA, 2014).

One of the greatest concerns of the government is about the life of the ex-fighters after demobilization. The economic reintegration has proven to be arduous in a number of DDR processes as a result of lack of education and insufficient job skills. (NUSSIO; HOWE, 2012; JOHNSON; JONSSON, 2013). Some other difficulties are due to the 'welfarism' character of PAHD and its institutional handouts. And still others because many ex-guerrillas moved to cities not only to find jobs, but also to establish new lives in anonymity and thus to rid themselves of the social stigma back in their villages in rural Colombia. However, having a rural background and generally no skills to compete in the urban scene they are marginalized. This makes their transition to civilian life more complicated. (ANAYA, 2007;

15 Solitude, hunger... Ever since you joined the guerrilla, an entire Colombia has been waiting for you with open arms to be productive. (Our translation).

16 ACR-Agencia Colombiana para la Reintegración. This is the Colombian state agency directly linked to the presidency of the country responsible for coordinating and executing together with other government agencies and private sector the social and economic reintegration of the demobilized guerrillas. (ACR, 2014).

17 The most recent ongoing peace talks with the FARC were announced in Havana/Cuba in August/2012. Ever since there has been a multiple theme agenda that covers the core elements of the Colombian conflict: Rural development, political participation, and the end of the conflict, drug trafficking and victims. (JOHNSON; JONSSON, 2013). This topic is out of the scope of this article, therefore we will not descend into details about it. 
NUSSIO; HOWE, 2012). Whenever marginalized they become easy prey for the organized crime. They are prone to be recruited for the obvious combat skills they possess. (JUDICE, 2007). To counter it, there is a proposal to convert some of demobilized FARC into rural police together with the idea to absorb others into the military. (ARIAS et ali, 2010; NUSSIO; HOWE, 2012). Yet these proposals are likely to face opposition in Colombia.

The social reintegration of ex-fighters is a hard task. In a research conducted by a government agency almost all of the ex-militants interviewed said that they needed to be an active part of their communities in order to be really reintegrated. (NUSSIO; HOWE, 2012). There has to be social opportunities available to the ex-fighters in local communities, organizations, and in the social matrix. (CARAMÉS; SANS, 2009). Therefore, the focus should be given not only to the demobilized but also to the communities in which they are trying to reintegrate. There have been community members' complaints about exaggerated attention to the demobilized people. This fact prevents the ex-combatants and the rest of the society to smoothly accept one another. (ANAYA, 2007; NUSSIO; HOWE, 2012).

Colombian government, citizens, policy makers and practitioners have been increasingly worried about the matter of security postdemobilization. Demobilization does not lead directly to security enhancement. There is research in some areas where the AUC - Auto Defensas Unidas de Colombia were demobilized that, after a first moment of reduced criminality, the gap was filled by either the same groups reemerging in new forms or other criminal organizations that destabilized the local social equilibrium bringing along even more crime and violence as the statistics proved. (JUDICE, 2007; PORCH; RASMUSSEN, 2008; NUSSIO; HOWE, 2012; JOHNSON; JONSSON, 2013). In the case of FARC, its fronts and columns have been based in isolated areas far from state presence. As FARC demobilizes the gaps have being slowly filled with governance and state control. The first measure of state's incrementing presence has been the decreasing of homicides in some of these areas. (NUSSIO; HOWE, 2012). As demobilization happens, policing and "protecting the population" are key actions to strengthen state reach and manage post-demobilization violence. (JUDICE, 2007; NUSSIO; HOWE, 2012; JOHNSON; JONSSON, 2013). 
There is an issue that is one of the most difficult to be solved: the drug trafficking. FARC has been a major player in Colombia's cocaine business for nearly three decades now. It has managed to involve itself in all phases of the business, from overseeing the harvest of coca leaves, guarding cocaine producing laboratories and illegal airstrips through taxing production, organizing markets and exportation. (SAAB; TAYLOR, 2008). Their demobilization may encourage other criminals to take advantage of the existing structure and move on with the business ${ }^{18}$. FARC commanders may simply sell their business to some criminal organization eager to build up in the vacuum FARC leaves behind. (NUSSIO; HOWE, 2012; INCE, 2013). As the drug business controlled by FARC is something large-scale and professional, there are not many criminal organizations up to taking control of it. One of the likely successors is the left-wing guerrilla ELN - Ejército de Liberación Nacional which, given its structure, it is capable enough to take over FARC's current operations. (INCE, 2013).

One aspect that still haunts PAHD operators and the Colombian government as a whole is the ex-fighters prospects of recidivism. (PORCH; RASMUSSEN, 2008; SARRIAS, 2011; NUSSIO; HOWE, 2012). Are the foot soldiers of FARC really stopping fighting? As said before, ex-members of FARC may be sought out by criminal groups for their particular expertise and connections. Yet there are specific factors relevant for recidivism within FARC. It is a vertically organized frame where discipline is strict. Fighters sign up for life. Its codes of conduct are tough. All wealth made via drug trade, kidnapping, extortion, etc. goes straight into the organization. Looting and personal wealth are strictly forbidden, even in higher ranks due to their rules and ideology. (NUSSIO; HOWE, 2012). The political dimension plays an important part in the issue. Unlike the AUC DDR for instance, the DDR process is less vulnerable within FARC demobilized personnel, provided that PAHD ensures meaningful political participation and employment for ex-FARC large peasant-based guerrillas. (PORCH; RASMUSSEN, 2008; ARIAS et ali, 2010; SARRIAS, 2011; NUSSIO; HOWE, 2012). Furthermore, the government has to constantly deal with the juridical insecurity felt by the demobilized whose criminal charges are in the limbo of the law $975 / 2005$ and its constitutional issues. It is obscure for

18 In the case of the demobilization of the AUC this has happened in some areas. As AUC was heavily involved in drug trafficking, their dissolution has not led to the collapse of the illegal trade; instead, post demobilization armed groups surfaced and took it over. (PORCH; RASMUSSEN, 2008; CARAMÉS; SANS, 2009; NUSSIO; HOWE, 2012). 
them their situation regarded the promised amnesty and reduced sentence benefits. (ARIAS et ali 2010; NUSSIO; HOWE, 2012). They fear for their future, and that is another spark for recidivism.

A decisive point that should definitively not be overlooked is the importance ofFARC mid-level commanders in the PAHD. These individuals possess a powerful place in the ranks: they are the link between the top-level commanders whom they are close, and the rank and file, whom they deal with on a daily basis. For this reason they are the sub-group that experience a greater loss in terms of status in the demobilization process, and hence can turn into potential spoilers. (ARIAS et ali, 2010; NUSSIO; HOWE, 2012).

From 2002 to mid 2014 19,576 FARC fighters have demobilized. Among them an average of $9 \%$ are mid-level commanders. (MINDEFENSA, 2014; ARIAS et ali, 2010). The statistics also show that the proportion between rank and file and mid-level commanders demobilized personnel has decreased through the years having had its peak in 2008. In 2002 for each mid-level commander demobilized there were 27 rank and files, in 2008 this proportion became 1 to 3. (ARIAS et ali, 2010).

Efforts to demobilize mid-level commanders surely are of a strategic importance as they are the key players in the chain of command of FARC. Their knowledge of the terrain, local people whom they deal with, and the troops is invaluable. As they conduct combat and reconnaissance, they are the ones that collect combat intelligence. They are also responsible for finding, keeping and covering mobility corridors and for the planning of all routine and small-scale operations. They are generally assigned to a Front in the area they come from, for it is crucial that they can deal well both with the terrain and the population. Their strategic advantage in fighting the Colombian forces lies in this. Their demobilization has caused already disruption in FARC's structure. (ARIAS et ali, 2010).

The increasing demobilization of mid-level commanders did not happen by chance. This was the result of a governmental push and its based on three variables. In 2006, the current president of Colombia, Juan Manuel Santos was then the newly assigned Defense Minister. He worked hard on boosting the capability of the aforementioned Colombia's Reintegration Agency (ACR). (ARIAS et ali, 2010). The topic of 'mid-level commanders demobilization' was given a special permanent attention. Following that 
lead, Defense Minister Santos issued new directives towards the military and police forces ${ }^{19}$. Accordingly, under these directives they were assigned an additional job, apart from direct combat engagement, which was to work harder on the demobilization efforts. (MINDEFENSA, 2014). And at last, the demobilization achievements were enhanced after a greater collaboration between PAHD and ACR concerning their particular knowledge, capabilities and exchange of information. (ARIAS, et ali, 2010; MINDEFENSA, 2014).

\section{CONCLUSION REMARKS}

The enduring demobilization of the insurgents has been crippling the combat efficiency of FARC. Even though its ability to replace the deserters remain operational, FARC does not have a rest area anymore where it can train them effectively since it was pushed to far flung areas of the country and its mobility corridors were cut off.

The last six to seven years saw a high turnover of FARC senior personnel. That means that current FARC leadership might not have the same level of authority as its previous leaders. (INCE, 2013; NADER, 2013). This is a crack that Colombian government can fully exploit to be able to coax FARC into submission. Accordingly, there should be further and continuous enhancement in the PAHD and its methodology to influence FARC members to desert, especially the mid-level commanders. But that policy should be accompanied with a competent vehicle to help them shift to civilian life ${ }^{20}$. That said and done, there should also be a way to advertise efficiently to the remaining fighters that the demobilized personnel have earned substantially by leaving the guerrilla, in opposition to what they were told by their guerrilla commanders that they would end up killed by Colombian security forces.

19 Ministerial Directive 15/2007: The military and police commanders must prioritize efforts to incentive the individual demobilization of guerrilla fighters. Ministerial Directive 300-28/2007: The operational results of the public forces will be calculated upon individual demobilization results prior to combat/capture results. (MINDEFENSA, 2007).

20 One goal of the DDR should be demilitarizing the models of masculinity that these men and women have, particularly when these men have so little access to civilian symbols of masculine prestige such as education, legal income or decent housing. (THEIDON, 2009). 
Speaking of the mid-level commanders, the Colombian security forces have been greatly benefited in the strategic and tactical levels ${ }^{21}$ by the information they collected through countless interviews and debriefings with these men and women. For this reason alone the PAHD has to set some criteria for differentiation whenever these are demobilized. They are not to be offered the same it is done with the rank and file, for they have a different need. As said before, they endure a loss of status when they leave the guerrilla because PAHD is still somewhat not prepared to accommodate them. There should be something more individualized, a procedure to sort them out; something that could access their ability for teamwork, their initiative, their experience in general management and discipline. Thus, they would have a better chance to be directed to jobs that require this type of qualification. That would not only greatly help the mid-level commanders already demobilized to convince others to desert the ranks of FARC, but also it would be a great move to prevent recidivism.

The power vacuum is another permanent concern. The ex-militants generally say that they never witnessed any state presence in the areas they operated. FARC came up and took control, simple as that. FARC became both heroes and villains. People feared and respected them because they were the authority; they performed all kinds of public service. They were the law. For this reason, the state needs to appear and stay for good. They need to perform public service; they should begin at least providing small gestures aiding the population in their basics, and besides, it is a must to create law and order, and to exert its authority. But it has to be a long-lasting effort. The population has to understand that the state is something to be respected, not to be feared. With that in mind the government will be able to counter FARC propaganda that says the government is repressive, corrupt and do not care about peasants.

Notwithstanding the government's effort in occupying the areas once in the hands of FARC, there is an additional problem, which is the filling of FARC's criminal void. If we consider the best-case scenario should the peace talks succeed, there is no doubt that FARC will quickly be replaced by some criminal organization in the drug trafficking chain. Most likely the already existent layers of local criminal actors present in FARC territories will vie to gain control over FARC's current drug businesses and other criminal

21 That happened not only in the combat front but also in preventing terrorist attacks and rescuing kidnapped civilians and military alike. 
activities. Once the organized crime takes over, a new threat is afloat and this will require a different set of strategies. However, like organized crime in any other country, this issue is something that will never be completely fixed, at its best the Colombian government will be able to contain it and repress it. Nonetheless, as long as FARC is being defeated, the government will be able to redirect the resources spent on fighting FARC militarily towards the fight against organized crime and also the improvement of its presence in the neglected areas of the country.

Colombia altogether has won many battles against FARC, but it has not won the war. The promise for peace in Colombia remains uncertain. Yet the possibility is greater than in the last five decades. The widespread optimism since the 2012 negotiations began has since been cooled by repeated FARC statements attempting to change the framework of the talks. On the other side, the Colombian government is inclined to demand a victor's peace. Yet FARC wants equal footing. Neither of them seems rational. However they agree in one aspect: both know they cannot expect to win the conflict solely with bombs and bullets.

\section{Desmobilização e Reintegração dos COMBATENTES DAS FARC: OS DESAFIOS ENFRENTADOS PARA ACABAR COM A GUERRA}

\section{RESUMO}

As Fuerzas Armadas Revolucionarias de Colombia - FARC consolidaram sua posição como o mais longo e resiliente movimento guerrilheiro em todo o continente americano. As FARC têm sido sistematicamente enfraquecidas após perdas constantes de suas lideranças, juntamente com mais da metade de seus integrantes e um número substancial de seus experientes líderes intermediários. Ainda assim a paz não parece próxima. A guerra civil colombiana é o estereótipo do conflito de difícil solução. As forças militares e de segurança colombianas têm se revelado cada dia mais 
poderosas, ainda assim, a guerrilha, apesar de combalida, continua firme e resiliente. O governo colombiano acredita que vive um momento propício, em que o programa de desmobilização parece ser a saída para o conflito. O programa colombiano de desmobilização se chama Programa de Atención Humanitaria al Desmovilizado - PAHD. Este programa tem sido bem recebido e aprovado pela população, bem como pelos desmobilizados. Uma das maiores preocupaçôes do governo tem sido acerca da vida dos ex-guerrilheiros após sua desmobilização. A reintegração profissional e econômica dos ex-guerrilheiros têm sido difícil, e com isso o seu retorno à guerrilha pode se tornar um problema. Porém, há outras questões concernentes à derrota das FARC que têm de ser observadas juntamente com o programa de desmobilização, para que a paz se torne finalmente possível.

Palavras-Chave: FARC. Guerrilha. Colômbia. Forças Militares. Segurança. Insurgência. Recrutamento. Desmobilização. Reintegração. Organização Criminal. Governança.

\section{Desmovilización Y Reintegración DE COMbatientes DE LAS FARC: los DEsafíos ENFRENTADOS PARA PONER FIN A LA GUERRA}

\section{RESUMEN}

Las Fuerzas Armadas Revolucionarias de Colombia - FARC consolidó su posición como el movimiento guerrillero más largo y flexible en todas las Américas. Las FARC se han debilitado sistemáticamente después de la pérdida constante de sus líderes, junto con más de la mitad de sus miembros y un número considerable de sus líderes provisionales experimentados. Sin embargo, la paz no parece cercana. La guerra civil colombiana es el estereotipo de conflicto de difícil resolución. Las fuerzas militares y de seguridad colombianas han demostrado ser más poderosas cada día, sin embargo, la guerrilla, aunque debilitada, es todavía fuerte y resistente. El gobierno colombiano cree vivir un buen momento para el programa de desmovilización que parece ser la solución al conflicto. El programa de desmovilización en Colombia se llama PAHD - Programa de Atención Humanitaria al Desmovilizado. Este programa ha sido bien recibido y aprobado por la población y por los desmovilizados. Una de las mayores preocupaciones del gobierno es la vida de los ex guerrilleros después de su desmovilización. La reintegración profesional y económica de los ex combatientes es difícil, por lo que su regreso a la guerrilla puede convertirse en un problema. Pero hay otras cuestiones relativas a la derrota de las FARC que tienen que ser observadas junto con el programa de desmovilización, para que la paz sea finalmente posible.

Palabras Clave: FARC. Guerrilla. Colombia. Las fuerzas militares. Seguridad. Insurgencia. Reclutamiento. Desmovilización. Reintegración. Organización criminal. Gobernabilidad. 


\section{REFERENCES}

ACR. Agencia Colombiana para La Reintegración. 2014. Available at: http://www.reintegracion.gov.co Acessed: Aug, 3rd, 2014.

ANAYA, Liliana. Individual demobilization and reintegration process in Colombia: implementation, challenges and former combatant's perspectives. Intervention. Volume 5. No 3. 2007. (179-190). Available at: http://www.ourmediaourselves.com/archives/53pdf/ anaya.pdf Acessed: Jun, 14th, 2014.

ARIAS, Gerson Ívan; HERRERA, Natalia; PRIETO, Carlos Andrés. Mandos Medios de las FARC y su proceso de desmovilización en el conflicto colombiano: una apuesta para la paz o para la Guerra? Informes FIP. Fundación Ideas para la paz. 2010. Available at: http://www.isn.ethz.ch/Digital-Library/Publications/ Detail/?lng=en\&id=152325 Acessed: Jun, 25th, 2014

BAÉZ, Carolina Quiroga. Aumentan significativamente las entregas voluntarias. Ejército Nacional de Colombia. En Guardia por Colombia. Edición 111. 2009.

CARAMÉS, Albert; SANS, Eneko. DDR 2009. Analysis of Disarmament, Demobilization and Reintegration Programs in the world during 2008. Universidad Autónoma de Barcelona. Bellaterra. School for a Culture of Peace. 2009. Available at: http://escolapau.uab.es/img/ programas/desarme/ddr/ddr2009i.pdf Acessed: Jun, 12th, 2014.

CIDH - Comisión Interamericana de Derechos Humanos. OEA Interamerican Comission On Human Rights. Follow Up on the Demobilization Process of AUC in Colombia. 2007. Available at: http://www.cidh.oas.org/pdf\%20files/Colombia-DemobilizationAUC\%202008.pdf Acessed, Jul, 3rd, 2014.

CJA - Center for Justice and Accountability. Colombia: The justice and peace law. 2014. Available at: http://www.cja.org/article. php?id=863 Acessed: Jul, 24th, 2014.

COLOMBIA. Ministerio de Relaciones Exteriores. Coordinación de Desarme y Seguridad Internacional. Reporte Nacional. 2008. Available at: http://www.un.org/disarmament/convarms/BMS/bms3/1BMS3Pages /1NationalReports/Colombia\%20-full.pdf Acessed: Aug, 1st, 2014. 
CRANDALL, Russel. Requiem for the FARC? Survival. Volume 53. No 4. 2011. Available at: http://www.iiss.org/en/publications/survival/ sections/2011-2760/survival--global-politics-and-strategy-augustseptember-2011-66cf/53-4-18-crandall-closing-argument-8f6a Acessed: Jun, 12th, 2014.

CRISIS GROUP. Colombia: Por fin la paz? International Crisis Group. Informe sobre América Latina no 45. 2012. Available at: http:// www.crisisgroup.org/ /media/Files/latin-america/colombia/ Spanish\%20translations/045-colombia-peace-at-last-spanish.pdf Acessed: Jun, 10th, 2014.

CUNNINHAM, Dan; EVERTON, Sean; WILSON, Greg. Brokers and Key Players in the internalization of the FARC. Studies in Conflict and Terrorism. Volume 36. Issue 6. 2013. Available at: http://www. tandfonline.com/doi/abs/10.1080/1057610X.2013.784603\#previ ew Acessed: Jun, 27th, 2014.

ECCARIUS-KELLY, Vera. Surreptitious Lifelines: A structural Analysis of the FARC and the PKK. Terrorism and Political Violence. Volume 24. Issue 2. 2012. (235-258). Available at: http://www.tandfonline.com/doi/abs/1 0.1080/09546553.2011.651182\#preview Acessed: Aug, 14th, 2014.

ENC. Ejército Nacional de Colombia. Training Material. Historia de las FARC/ Estructura de las FARC/ Finalidad de las conferencias/ Empleo General. 2009.

INCE, Matt. Filling the FARC shaped void. Potential insecurity in postconflict Colombia. RUSI Journal. Volume 158. No 5. 2013. (2634). Available at: http://www.tandfonline.com/doi/abs/10.1080/03 071847.2013.847708\#preview Acessed: Aug, 26th, 2014.

INCE, Matt. Defeating Colombia's oldest insurgency. Prospects for peace and reconciliation with the FARC. RUSI Journal. Volume 158. No 1. 2013. (20-27). Available at: https://www.rusi.org/publications/ journal/ref:A51309D89C904A/ Acessed: Jul, 1st, 2014.

JONSSON, Michael; JOHNSON, Kyle. Colombia: Ending the forever war. Survival: Global Politics and Strategy. Volume 55. Issue 1. 2013. (67-86). Available at: http://www.tandfonline.com/doi/abs/10.1080/ 00396338.2013.767407\#.U9WOoVaT5P4 Acessed: Jul, 14th, 2014. 
JUDICE, Douglas. Colombia's attempt at peace: an analysis of the demobilization of the Auto-Defensas Unidas de Colombia (AUC). Naval Postgraduate School. Monterrey/CA. 2007. Available at: http:// calhoun.nps.edu/public/handle/10945/3589 Acessed: Jul, 16th, 2014.

LIBICKI, Martin; CONNABLE, Ben. How insurgencies end. Santa Monica/CA. RAND. 2010. Available at: http://www.rand.org/ content/dam/rand/pubs/monographs/2010/RAND_MG965.pdf Acessed: Jan, 19th, 2014.

MARKS, Thomas A. A model counterinsurgency: Uribe's Colombia (20022006) vs FARC. Military Review. March/April. 2007. Available at: http://usacac.army.mil/CAC2/MilitaryReview/Archives/English/ MilitaryReview_20070430_art010.pdf Acessed: May, 23rd, 2014.

MENDEZ, Andrea. Militarized gender performativity: Women's demobilization in Colombia's FARC and AUC. Department of Political Studies. Queen's University. Kingston. Ontario. Canada. 2012. Available at: http://www.peacewomen.org/assets/file/ddrmilitarized_gender_performativity-_women_and_demobilization_ in_colombias_farc_and_auc.pdf Acessed:Jun, 2nd, 2014.

MINDEFENSA. Ministerio de la Defensa. Ley 975/2005. 2005. Ley de Justicia y Paz. Available at: http://www.mindefensa.gov.co/irj/ go/km/docs/Mindefensa/Documentos/descargas/normatividad/ PoliticaAsuntosInt/Desmovilizados/NormatividadPAHD/7405_ Ley_975_de_2005_.pdf Acessed: Jun, 23rd, 2014.

MINDEFENSA. Directiva Permanente 300-28/2007. 2007. Available at: http://www.mindefensa.gov.co/irj/go/ $/ \mathrm{mm} / \mathrm{docs} /$ Mindefensa/ Documentos/descargas/Documentos_Home2/dir_cgfm_30028_20112007.pdf Acessed: July, 12th, 2014.

MINDEFENSA. Ministerio de la Defensa. PAHD 2014. Available at: https:// www.mindefensa.gov.co/irj/portal/Mindefensa?NavigationTarget=nav url://4ce4836ab8c2ca6452e6b370406191ae Acessed: Sep,2nd, 2014.

MOLANO, Alfredo. The evolution of the FARC: A guerrilla's group long history. NACLA report on the Americas. Volume 34. No 2. 2000. Available at: https://nacla.org/article/evolution-farc-guerrillagroups-long-history Acessed: Jun, 12th, 2014.

NACIÓN. Crónica de una Desilusión. Semana. 2010. Available at: http:// 
www.semana.com/nacion/articulo/cronica-desilusion/120533-3 Acessed: July, 2nd, 2014.

NADER, Paul S. Former's members perspectives are key to impacting the FARC. JSS. Journal of Strategic Security. Volume 6. No 1. 2013. (7383). Available at: http://scholarcommons.usf.edu/cgi/viewcontent. cgi article $=1213 \&$ context $=$ jss Acessed: Jun, 29th, 2014 .

NUSSIO, Enzo; HOWE, Kimberly. What if FARC demobilizes? Stability. Volume 1. No 1. 2012. (58-67). Available at: http://www. stabilityjournal.org/article/view/sta.aj/24 Acessed: Jul, 17th, 2014.

NYTIMES. NEW YORK TIMES. Colombia’s capitulation. 2005. Available at: http://www.nytimes.com/2005/07/05/opinion/05ihtedcolombia.html?_r=0 Acessed: Jul, 1st, 2014.

OSPINA, Carlos; MARKS, Thomas. Colombia: Changing strategy amidst struggle. Small Wars and Insurgencies. Volume 25. No 2. 2014. (354-371). Available at: http://www.tandfonline.com/doi/abs/1 0.1080/09592318.2014.903641 ?queryID=\%24\%7BresultBean. queryID\%7D\#preview Acessed: Jul, 23rd, 2014.

PÉCAUT, Daniel. Las FARC: Una guerrilla sin fin o sin fines? Bogotá/ Colombia. Editorial Norma. 2008.

PECENY, Mark; DURNAN, Michael. The FARC's best friend: U.S. Antidrug policies and the deepening of Colombia's civil war in the 1990s. Project Muse. Latin American Politics and Society. Volume 48. No 2. 2006. (95-116). Available at: https://muse.jhu.edu/ login?auth=0\&type $=$ summary\&url=/journals/latin_american_politics_ and_society/v048/48.2peceny01.html Acessed: Aug, 14th, 2014.

PENAARANDA, Ricardo; BERGQUIST, Charles; GONZALO, Sánchez. Violence in Colombia, 1990-2000: waging war and negotiating peace. Scholarly Resources. Wilmington/DE. 2003. Available at: http://books.google.com.br/books?id=EjC9UcS7Rn0C\&p $\mathrm{g}=$ PR7\&lpg=PR7\&dq=violence + in + colombia,$+1990+2000+$ waging + war+and + negotiating + peace\&source $=$ bl\&ots $=\mathrm{K} 4 \mathrm{Xc}$ 89n_Tb\&sig=hWL7X9SXEZAXjSpdUFxfsXE8wAE\&hl=ptBR\&sa $=X \&$ ei $=$ n6HVU_XPGOnLsATD6YKQDA\&ved $=0$ CEY $\mathrm{Q} 6 \mathrm{AEwBA} \#_{\mathrm{v}}=$ onepage\&q $=$ violence\%20in\%20 colombia\%2C\%20 1990\%202000\%20waging\%20war\%20and\%20negotiating\%20 peace $\& f=$ false Acessed: Aug, 12th, 2014. 
PHILLIPS, Anne. Once Were Warriors. Colombia's Programs to turn FARC fighters into civilians. Foreign Affairs. New York/NY, October. 2012. Available at: http://www.foreignaffairs.com/articles/138377/annephillips/once-were-warriors Acessed: Jun, 1st, 2014.

PORCH, Douglas; RASMUSSEN, Maria Jose. Demobilization of paramilitaries in Colombia: transformation or transition?

Studies in Conflict and Terrorism. Volume 31. No 6. (520540). 2008. Available at: http://www.tandfonline.com/doi/ abs/10.1080/10576100802064841 Acessed: Jun, 24th, 2014.

REFSHAUGE, Esteban. Tanja Nijmeijer. Profiles. Colombia Reports. 2012. Available at: http://colombiareports.co/tanja-nijmeijer/. Acessed: Jun, 11th, 2014.

RESTREPO, Jorge; SPAGAT, Michael. Colombia's tipping point?

Survival: Global Politics and Strategy. Volume 47. No 2. 2006. (131-152). Available at: http://www.tandfonline.com/doi/ abs/10.1080/00396330500156602\#.U9woF1aT5P4 Acessed: May, 21 st, 2014.

RUEDA, Zenaida. Confesiones de una guerrillera. Bogotá/Colombia. Editora Planeta. 2009.

SAAB, Bilal; TAYLOR, Alexandra. Criminality and armed groups: A comparative study of FARC and paramilitary groups in Colombia. Studies in Conflict and Terrorism. Volume 32. 2009. (455-475). Available at: http://www.tandfonline.com/doi/abs/10.1080/10576 100902892570\#preview Acessed: May, 25th, 2014.

SARMIENTO, Alvaro Villaraga. Experiencias históricas recientes de reintegración de excombatientes en Colombia. Colombia Internacional. Volumen 77. 2013. (107-140). Available at: http:// colombiainternacional.uniandes.edu.co/view.php/9124/view.php Acessed: Jun, 11th, 2014.

SARRIAS, Jose Armando Cárdenas. Los Agujeros Negros del Desarme. La desmovilización Individual en el gobierno Uribe Vélez 2002-2010. Departamento de Historia. Universidad Nacional de Colombia. 2011. Available at: http://www.bdigital.unal.edu.co/6247/1/ Joséarmandocárdenassarrias.2011.pdf Acessed: May, 6th, 2014. 
THEIDON, Kimberly. Reconstructing masculinities: the disarmament, demobilization, and reintegration of former combatants in Colombia. Human Rights Quarterly. Volume 31. (1-34). 2009. Available at: http://www.hks.harvard.edu/cchrp/initiatives/ latin_america/pdf/Theidon_HumanRightsQuarterly_2009_ DemobilizedInterviews.pdf Acessed: May, 24th, 2014.

UN. United Nations. Children and Armed Conflict. The Paris Principles. 2007. Available at: https://childrenandarmedconflict.un.org/ publications/ParisPrinciples_EN.pdf Acessed: July, 2nd, 2014.

UNDDR - United Nations. DDR. Demobilization, Disarmament and Reintegration. 2014 Available at: http://www.unddr.org/what-isddr/introduction_1.aspx Acessed: Jun, 11th, 2014.

UNHCR. United Nations High Commission for Refugees. 2014. Available at: http://www.unhcr.org/cgi-bin/texis/vtx/ page page $=49$ e492ad6\&submit $=$ GO Acessed: July, 29th, 2014 .

WENTZ, Laurel. Colombia uses ads to persuade rebels to turn themselves in. Advertising Age. 2009. Available at: http://adage.com/article/ global-news/colombia-ads-persuade-rebels-turn/140548/ Acessed: Jun, 11th, 2014.

WHITE, Jonathan. Terrorism and Homeland Security. Belmont/CA. 7th Edition. Wadsworth. 2012.

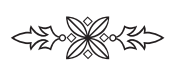

